\title{
The problem of the absorption of national legal cultures by the emerging national legal anti-culture
}

\author{
Anatoly Nikolaevich Afanasyev ${ }^{1}$, Aleksey Vyacheslavovich Samoilov, Ekaterina \\ Vladimirovna Pashkova, Izmir Kerimkhanovich Sarukhanov, and Victoria Aleksandrovna \\ Ufimtseva \\ Kursk State University, Department of Criminal Law and Procedure, Kursk, Russia
}

\begin{abstract}
Annotation. The purpose of the research is to show the organizational and legal mechanism of new United States' not powerful approach to the implementation and simultaneous convergence of its legal culture at the global level. General, general scientific and special methods were used in the research. Theoretical basis of the research are the basic laws of states, international universal and regional treaties, doctrinal works revealing the concept of legal culture, scientific articles of Russian and foreign scholars dealing with the content, preservation and transformation of legal cultures. The result of the research was a comparative presentation of the basic values of national legal cultures and global legal anti-culture; ways of "de-substantiation" of national legal cultures; ways of absorption of national legal cultures by global legal anti-culture. The novelty of the research lies in the fact that the article for the first time shows the organizational and legal mechanism of the not powerful way of replacing the global legal anti-culture with national legal cultures. For this purpose, traditional national legal cultures, as well as the global legal anti-culture, are considered in terms of their basic value content; shows ways to absorb global legal anti-culture through "de-substantiation" collective (public) and individual (personal) identities; highlights the organizational mechanism of global legal anti-culture takeover. This research contributes to the comprehension of the content, processes, and ways of forming a global legal anti-culture, as well as to the convergence of states in the vision of this problem and the search for answers to emerging challenges.
\end{abstract}

Keywords: national legal culture, state sovereignty, civilizational values, global governance

\section{Introduction}

The prerequisites for this research were continuous attempts to reform the legal system of Russia over the past 30 years by representatives of transatlantic civilization in the face of

\footnotetext{
${ }^{1}$ Corresponding author: vipmaker@mail.ru
} 
the United States and EU countries within the framework of the unipolar world of domination of Euro-Atlantic civilization.

At a meeting with faction leaders in the Kremlin in March 2020, Russian President Vladimir Putin stated the need to increase Russia's state sovereignty in connection with amendments to the Russian Constitution [1]. Also at a meeting with faction leaders on February 17, 2021, V.V. Putin emphasized avoiding blows to Russia's sovereignty, to the right of the people to be the master of their own land [2].

In his keynote address, Mr. Blinken, the United States Secretary of State, announced a new nonviolent U.S. approach to promoting its values in the world by pushing states to implement key reforms and encourage democratic behavior [3].

Based on the above, the authors put forward the following research hypothesis: the organizational and legal mechanism of GLNAC takeover involves the legalization of the commercialization of state (public) and human (individual gender and personality) identities through multi-vector network convergence processes. To investigate the hypothesis of the research, the authors set the following objectives: 1) to examine national legal culture as well as global legal anti-culture in terms of their underlying value content; 2) to show the ways in which GLNAC is absorbed through the "desubstantiation" of collective (public) and individual (personal) identities; 3 ) to describe the organizational mechanism of GLNAC absorption

\section{Methods}

The methodological basis of the research are universal, general scientific and private scientific methods of knowledge used by the legal science in the object-subject sphere of knowledge of the general theory of law.

In the process of research, the emphasis was made on legal comparativism, applied historical-legal, comparative-legal, formal-legal and other special methods of scientific knowledge.

\section{Results}

Modern civilizational and national legal cultures are based on traditional values that are not subject to change and commercialization: spiritual and moral - faith in God, in the good, which is reflected in the principles of law (justice, fairness, impartiality, objectivity); collective (public) - the international community represented by the United Nations, state, nation, family; individual sexual (man, woman, boy, girl); personal (father, mother, son, daughter).

The global legal anti-culture is based on the denial of spiritual and moral values.

1.The dissolution of civilizational and national identities is carried out through the harmonization of legal standards.

2. The main way of GLNAC absorption is reduced to a network convergence impact on civilizational and national legal cultures.

\section{Discussion}

Legal culture is a result of the historical development of the state, which arises in turn as a result of the cultural development of the people, its spiritual and cultural tradition [4]. 
The loss or absorption of legal culture threatens the loss of state sovereignty and the disappearance of a people from the political map of the world.

The UN Charter guarantees the preservation of national legal cultures by enshrining the fundamental principle of international law of the sovereign equality of states (UN Charter).

Today, the world is once again faced with the resurgence of the ideology of global supremacy, which aims to form a global civilizational legal anti-culture by absorbing traditional national and civilizational legal cultures and replacing them with anti-traditional global values [5].

Legal culture is also a civilizational product. In the context of legal culture, a religious approach seems appropriate as the basis for the current classification of modern civilizations [6]. According to Lukasheva, the civilizational approach is conditioned by the nature of this or that culture [7]. "Culture has religious foundations", wrote Berdyaev [8]. He also repeatedly emphasized the difference between the moral consciousness of Russian and Western people [9].

Lotman noted the lack of uniformity in the social order of Russia and the West, determining that "completely overlapping concepts radically change their meaning depending on whether they are written and perceived in Western Europe or Russia" [10]. Frank explained the contrast between the Western and Russian worldviews as individualistic and collective [11]. Krasheninnikova also emphasizes that cultural and political values have a decisive influence on the genotype of a nation [12].

For Russian civilization, the Orthodox tradition is culture-forming [13].

Modern international law enshrines the principle of peaceful coexistence of national legal cultures, which is reflected primarily in the principles of sovereign equality of states and non-interference in internal affairs of the UN Charter (UN Charter).

Traditional legal cultures, at their core, regard the following values as enduring, non-commercial, invariable, and irrevocable under any circumstances: state, nation, family, father, mother, son, daughter, man, woman.

The global legal anti-culture is a culture of relativism, which translates personal relationships into commodity-money relationships, forcing one person to treat another as a thing. The commercialization of personal identity is linked to the sexual exploitation of children, to the rejection of the elderly as not of interest to the new culture [14].

According to proponents of the new legal anti-culture, transnational relations go beyond intrastate and international relations. They become multiculturalist, transhumanist [15].

From the perspective of representatives of the interests of the formation of a global civilizational anti-culture (GCA), states that adhere to the preservation of their legal cultures belong to populist or neo-nationalist regimes. The constitutionalism of such states, according to GCA proponents, misunderstands the sociological foundations of constitutional national democracy, shaped through processes of global norm making [16].

One part of this rulemaking is the international legal mechanism of the sovereign control market (SCM), whose main purpose is to create and reconcile the space between the rights of constituent states to territorial integrity and the rights of peoples to remedial separation. The territories of South Ossetia, Abkhazia, and Donbass are suggested as potential territories entering the sovereign control market under the non-traditional approach [17].

In the area of global civilizational gender rights, along with same-sex marriage, the GCA emphasizes polygamy as a fundamental right to marriage [18].

In the legal culture of Euro-Atlantic civilization, the right to personal identity, the realization of which is possible already in childhood, challenges the consent of the parents to the decision of the child, and requires social, educational and law enforcement 
institutions not only to implement as a matter of priority this right, but also to widely promote in society [19]).

The emerging global legal anti-culture has clear ideological overtones of loyalty to exclusively values that displace traditional ones and are associated with the commercialization of sovereign collective and individual identity.

In 2016, for example, the largest research of the political ideological preferences of American lawyers in the history of the United States was conducted [20]. This research provides a very accurate assessment of the political loyalties of lawyers in terms of staffing the processes of absorption of national and civilizational legal cultures by the global legal anti-culture.

International Regulatory Cooperation (IRC) plays the role of an organizational and legal mechanism for promoting a global legal anti-culture (shaped by the GPA by the national institutions of Euro-Atlantic civilization) at the international and national levels [21].

The ultimate goal of all these multi-vector network convergence processes boils down to the creation of a single global regulator governing one global positive regulatory law, forming a global legal anti-culture.

\section{Conclusion}

Modern national legal cultures are challenged by the Euro-Atlantic civilization, which attempts to replace national legal cultures with a global legal anti-culture. The replacement of national legal cultures by a global legal anti-culture, is a non-powerful way of transforming state power into global power, the transformation of national legal systems into a global legal system.

The ultimate goal of the emerging global legal anti-culture is a total, unlimited by nothing and no one, commercialization of public and individual identity, destroying traditional interstate, intrastate, personal and interpersonal relationships.

The research of this problem is promising in the research of the sectoral impact of global legal anti-culture on legal standards in all spheres of life of states and on the legal processes of protecting national interests and strengthening state sovereignty, as well as interstate cooperation.

\section{Reference}

1. V.V. Putin obosnoval neobkhodimost ukrepleniya suvereniteta [V.V. Putin substantiated the need to strengthen sovereignty]. Accessed on: June 27, 2021. [Online]. Available: https://rg.ru/2020/03/06/putin-obosnoval-neobhodimost-ukrepleniia-suvereniteta.html

2. V.V. Putin zayavil o nedopustimosti udarov po suverenitetu Rossii [V.V. Putin declared unacceptability of strikes on Russia's sovereignty]. Accessed on: June 27, 2021. [Online]. Available: https://rg.ru/2021/02/17/putin-zaiavil-o-nedopustimosti-udarov-po-suverenitetu-rossii.h tml

3. Blinken zaveril, chto SShA ne budut nasazhdat demokratiyu za rubezhom siloi [Blinken assured that the U.S. would not impose democracy abroad by force]. Accessed on: June 27, 2021. [Online]. Available: https://tass.ru/mezhdunarodnaya-panorama/10828285

4. R.Y. Semikashev, Culture: Manag., Econ., Law 4, 22-27 (2016)

5. P.A. Fedorova, Jurist, 10, 12-17 (2020) 
6. V.K. Tsechoev, A.R. Shvanderova, Teoriya gosudarstva i prava: Uchebnik [Theory of State and Law: Prometheus Textbook] (Prometey, 2017)

7. E.A. Lukasheva, Vestnik Rus. Acad. Sci. 77(2), 115-120 (2007)

8. N.A. Berdyaev, Filosofiya neravenstva [Philosophy of Inequality] (IMA-Press, Moscow, 1990)

9. N.A. Berdyaev, Russkaya ideya [The Russian Idea] (Pholio, Kharkov, 2000)

10. Y.M. Lotman, Istoriya i tipologiya russkoi kultury [History and Typology of Russian Culture] (Iskusstvo-SPB, Saint Petersburg, 2002)

11. S.L. Frank, Russkoe mirovozzrenie [Russian worldview] (Nauka, Saint Petersburg, 1996)

12. V. Krasheninnikova, Amerika-Rossiya: kholodnaya voina kultur. Kak amerikanskie tsennosti prelomlyayut videnie Rossii [America-Russia: A Cold War of Cultures. How American values refract the vision of Russia] (Evropa, Moscow, 2007)

13. Vystuplenie mitropolita Smolenskogo i Kaliningradskogo Kirilla na X VRNS [Speech by Metropolitan Kirill of Smolensk and Kaliningrad at the X VRNS]. Accessed on: June 27, 2021. [Online]. Available:

https://vrns.ru/documents/vystuplenie-mitropolita-smolenskogo-i-kaliningradskogo-kir illa-na-x-vrns/

14. Pope Francis, On the care of the common home (Vatican Press, 2015)

15. V.A. Shchipkov, Posle cheloveka. Ideologiya i propaganda transgumanizma v sovremennom mire [Ideology and propaganda of transhumanism in the modern world] (Russian Expert School, Moscow, 2018)

16. C. Thornhill, Int. Theory 12(1), 1-32 (2020). https://doi.org/10.1017/S1752971919000186

17. A. Gelpern, Duke Law J. 67, 65-83 (2017) https://dlj.law.duke.edu

18. M.J. Higdon, Duke Law J. 67, 79-143 (2017) https://dlj.law.duke.edu

19. A. Valongo, The Italian Law J. 06(01), 285-299 (2020) DOI 10.23815/2421-2156.ITALJ

20. A. Bonica, A.S. Chilton, M. Sen, J. Legal Analysis 8(2), 277-335 (2016). https://doi.org/10.1093/jla/lav011

21. J.B. Wiener, A. Alemanno, Law and Contemp. Probl. 78(4), 103-136 (2015) https://scholarship.law.duke.edu/lcp/vol78/iss4/ 